\title{
Enhancing supplier integration through e-design and e-negotiation in small and medium enterprises
}

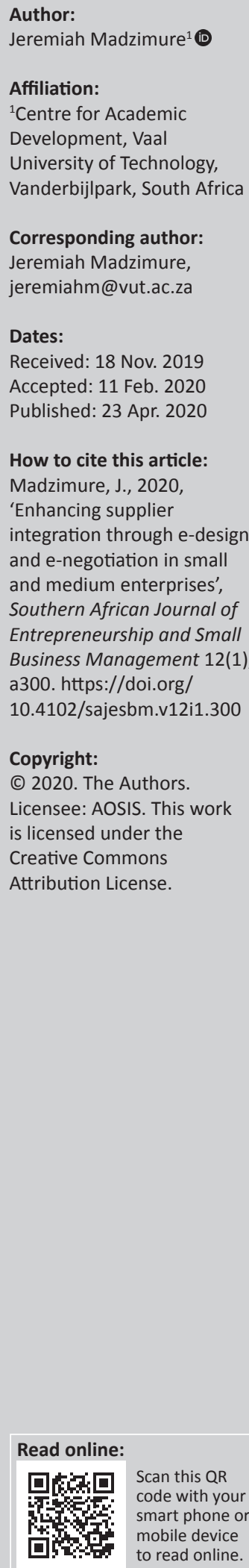

Background: The effects of globalisation, e-procurement and supply chain integration have become paramount to the success of supply chain management, especially to small and medium enterprises (SMEs) in a developing country context such as South Africa. Most studies on e-procurement and supplier integration have focused on large firms.

Aim: The aim of this study was to investigate how SMEs can enhance their supplier integration through e-design and e-negotiation.

Setting: This study was conducted in the Sedibeng region of the Gauteng province, South Africa.

Method: A quantitative research methodology was adopted in which the survey questionnaire was used to gather data from 283 SME owners and managers. A non-probability sampling employing convenience method was used. A structural equation modelling and the path modelling techniques were undertaken for this study.

Results: The principal finding of this study reveals that e-design has a positive and significant linear relationship with supplier integration. The findings further reveal that e-negotiation has a positive and significant linear relationship with supplier integration.

Conclusion: This study added practical value by developing an integrative model which might be used by SME practitioners in South Africa. The study recommended that SME owners and managers must effectively implement e-design and e-negotiation systems to increase the chance of integrating with their suppliers, thereby increasing the chance of improving performance and cutting supply chain costs.

Keywords: e-procurement; supplier integration; e-design; e-negotiation; configuration theory; SMEs; Gauteng Province.

\section{Introduction}

The effects of globalisation, e-procurement and supply chain integration have become paramount to the success of supply chain management especially to small and medium enterprises (SMEs) in a developing country context such as South Africa. To initiate the growth of SMEs, infrastructures such as e-procurement systems, together with supply chain integration, have been increasingly embedded in most firms (Vaast \& Walsham 2017:547). Therefore, the usage of various e-procurement systems and integration with suppliers timeously is considered as 'an innovation strategy action' (Mishra \& Agarwal 2010:249) and a firm's competitive advantage (Boehmke \& Hazen 2017:163). Most studies on e-procurement and supplier integration have focused on large firms (Chang, Tsai \& Hsu 2013:38).

Current knowledge involving SMEs in relation to e-procurement and supplier integration in developing countries such as South Africa is still limited, which creates a need for further research to occupy this research gap (Boehmke \& Hazen 2017:163). Furthermore, the South African government is increasingly adopting and encouraging e-procurement in SMEs. This is in line with the objectives of the National Development Plan (NDP) vision 2030, which include innovation, employment creation and the adoption of technology as mechanisms for the economic development of the country (Zarenda 2013:5). The South African government is eager to develop and streamline SME operations because SMEs make an important contribution to the economy. The relationship between e-procurement and supplier integration in SMEs in South Africa has not been fully investigated (Zheng et al. 2016:290).

Small and medium enterprises in developing countries face a myriad of challenges ranging from technology, globalisation, liberalisation and poor networking amongst the important players in the market, stiff competition from established firms to finances (Gumboh \& Gichira 2015:225). 
These challenges inhibit collaboration among supply chain partners and consequently affect SME performance. Lack of appropriate technology has been cited as impediment to SME collaboration, innovation and growth. Therefore, the most persistent challenge to greater supplier integration is lack of adequate information systems. Insufficient information system support is a barrier because collaboration is essentially information-based. Therefore, in the current climate of global supply chain competition, supplier integration is regarded as a prerequisite for winning performance (Njagi \& Ogutu 2014:191).

In the past decade (2009-2019), integrating suppliers and implementation of e-procurement systems has grown interest in major firms. The empirical investigation of the impact of e-procurement (e-design and e-negotiation) on SME supplier integration has received little attention (Georgise, Thoben \& Seifert 2014:1; Pooe \& Mahlangu 2017:238), and thus this study was conducted to fill this research gap.

The aim of this study was to investigate how SMEs can enhance their supplier integration through e-design and e-negotiation in the Gauteng Province of South Africa. The literature review of the research constructs (e-procurement, SMEs in South Africa and supplier integration) is discussed in the next section. Thereafter, the conceptual framework and hypothesis development follow. The research methodology, as well as results and discussion, is elaborated. Finally, conclusion, managerial implications, limitations of the study and directions for future research are explored in this article.

\section{Literature review}

\section{Theoretical framework}

The theoretical rationale underpinning this study is the Configuration Theory (Miller 1986:233). According to Miller (1986) and Sinha et al. (2005:389), the Configuration Theory allows for detailed examination of the dimension of supply chain integration and information technology (IT). This theory is appropriate because it can handle complicated organisational phenomena from a holistic perspective.

The configuration approach involves dominant gestalts or configurations of observable characteristics or behaviours that may lead to an outcome (Ward, Bickford \& Leong 1996:599). The Configuration Theory indicates the need to consider organisational arrangements, that is, configurations, to obtain high performance.

Therefore, this study considers the combination of e-procurement systems as the configuration of organisational resources to obtain better supplier integration.

\section{E-procurement}

E-procurement is one of the developments in the contemporary supply chain management (Chirchir, Ngeno \& Chepkwony 2015:26). E-procurement refers to 'an information technology (IT) based business model that facilitates the necessary processes conducted between business parties in a procurement transaction' (Smart 2010:423; Tai 2011:5398). Similarly, McCue and Roma (2012:58) define e-procurement as 'the use of information technology to facilitate business-tobusiness purchase transactions for materials and services'. It is clear from these two definitions that e-procurement is not merely a system for making purchases online but a link between customer and supplier.

E-procurement activities include 'enterprise resource planning (ERP); e-maintenance, repair and operations (E-MRO); e-sourcing; e-tendering; e-reverse auctioning; e-informing and e-market-places' (Smuts 2008:38).

According to McCue and Roma (2012:62), tools such as 'e-notice, e-auction, e-catalogue, e-dossier, e-submission and e-signatures' are components of e-procurement. In this study, e-design and e-negotiation are considered as the e-procurement systems. For this study, e-design refers to the 'setting of purchasing requirements on an electronic procurement system' (Chang et al. 2013:35). E-negotiation is defined as 'the process of conducting negotiations between business partners using electronic means' (Rinderle-Ma 2005:2). Thus, e-negotiation is used to make significant savings in the purchase of goods and services through the Internet (Scot \& Morrison 2007:332). Therefore, e-procurement if maintained properly will allow the company to establish and maintain competitive advantages and reduce staff time and paperwork (Tai 2011:5397).

\section{Small and medium enterprises in South Africa}

The National Small Business Act No. 26 of South Africa 1996, as amended in 2003, defines an SME as:

$[A]$ separate and distinct entity including co-operative enterprises and non-governmental organisations managed by one owner or more, including its branches or subsidiaries if any, is predominantly carried out in any sector or subsector of the economy mentioned in the schedule of size standards and can be classified as an SME by satisfying the criteria mentioned in the schedule of size standards (Government Gazette 2003:8).

According to the National Small Business Act No. 26 of South Africa 1996, as amended in 2003, in the Government Gazette (2003):

$[A]$ small enterprise in South Africa is one that employs 50 people or less and has a total turnover of up to R19m, with a total asset value of R3m. A medium enterprise employs from 50 up to 200 people and has a total turnover of R39m with a total asset value of R6m. (p. 8)

\section{Supplier integration}

Supplier integration refers to the process of interaction and collaboration between the firm and its suppliers to ensure effective flow of supplies (Flynn, Hou \& Zhao 2010:58; Zhao et al. 2011:372). Zhao et al. (2008:371) state that many organisations across the globe are creating co-operative, mutually beneficial partnerships with supply chain partners because of increasing global competition (Zhao et al. 2008:371). These authors further state that 'companies need to implement 
supply chain integration to meet the new challenges of the global competitive environment'.

Small and medium enterprises constantly face the problem of on-time delivery (Zhao, Feng \& Wang 2015:166). Through integration with suppliers, SMEs can share order and inventory information with suppliers. Furthermore, supplier integration, which includes proper communication, sharing information and working together with suppliers, can reduce upstream complexity (Zhao et al. 2015:167-168). The benefits of supplier integration are that it enhances responsiveness, flexibility and time-saving. Supplier integration also plays a role in reducing transaction costs through the reduction of uncertainties and reducing of production costs (Flynn et al. 2010:58). Therefore, supplier integration has a positive impact on operational performance (Yu et al. 2014:683). In supplier integration, opportunistic behaviours are greatly reduced under shared visions and cooperative goals (Prajogo, Oke \& Olhanger 2015:102; Wong, Tjosvold \& Yu 2005:782).

\section{The conceptual framework and hypotheses development}

The conceptual framework is provided in Figure 1. This highlights the proposed linkage between the constructs under investigation in this study.

\section{E-design and supplier integration}

E-design refers 'to the setting of purchasing requirements on an online procurement system' (Chang et al. 2013:35). E-design 'facilitates supplier involvement in the specification development process of a product. It also facilitates reduced time-to-market cycles by overcoming the silo effect of the traditionally sequential design activities' (Presutti 2003:220). This means that suppliers are involved in the design process. Thus, e-design is an important function in the e-procurement system as it enables collaboration of suppliers as well as enabling the purchasing process to be quick and efficient.

On the basis of the above, the first hypothesis is derived:

H1: E-design positively influences supplier integration in the SME sector.

\section{E-negotiation and supplier integration}

E-negotiation refers to business partners negotiating over Internet or IT platforms. E-negotiation is a key tool in e-procurement because it enables the collaboration of various

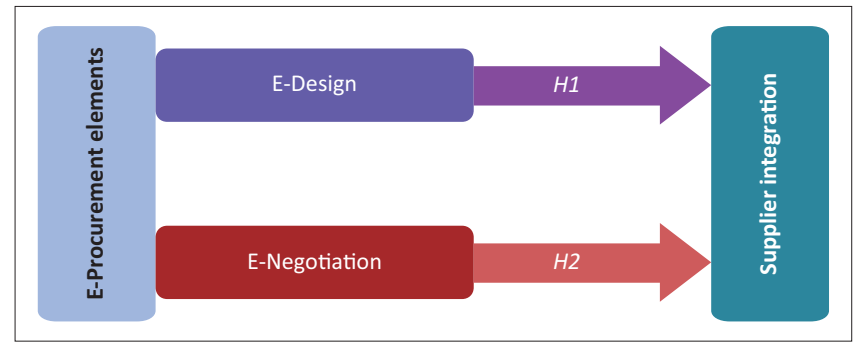

$H$, hypothesis.

FIGURE 1: The conceptual framework. key stakeholders particularly the suppliers. Thus, for e-negotiation to be successful, supplier integration is key in the process.

Therefore, on the basis of the above, the second and last hypothesis is derived:

H2: E-negotiation positively influences supplier integration in the SME sector.

\section{Research methodology}

In this study, a quantitative research methodology was adopted and considered more appropriate because addressing the research problem depended on the analysis of quantitative data collected on many survey questions around e-procurement and supplier integration in SMEs. Data were collected through a survey questionnaire. A total of 350 questionnaires were distributed to respondents, 294 were returned and 11 were discarded because of incomplete responses to different parts of the questionnaire. A total of 283 questionnaires were finally used in the study. Data were analysed with Statistical Package for the Social Sciences (SPSS) version 24 and Analysis of a Moment Structures (AMOS) software version 24 for the structural equation modelling (SEM).

\section{Measuring instrument and operationalisation}

The questionnaire used in this study consisted out of three sections. Section A consists of four items and sought general demographic information about the respondents and SME profile. Section B consisted out of eight items, which covered all the two e-procurement systems (e-design and e-negotiation), adapted from Chang et al. (2013:39) and Ombat (2015:718). Section C seeked respondents' views on supplier integration, using eight items adapted from Zhao et al. (2013:130). All measurement scales are measured using 5-point Likerttype scales, where $1=$ strongly disagree and $5=$ strongly agree. The Likert-type scale was adopted mainly because it was easy to analyse the quantitative information and draw conclusions.

\section{Reliability tests}

Reliability in this study was ascertained using Cronbach's alpha coefficient, the average variance extracted (AVE), item-to-total values and composite reliability (CR). Table 1 presents the results of the reliability tests.

In this study, the results of the CR range from 0.77 to 0.94 as shown in Table 1 and thus confirm the existence of internal reliability for all constructs of the study. The measurement items used in this study were reliable because all the Cronbach's alpha coefficients were above the recommended 0.7 threshold.

\section{Validity tests}

Validity is the extent to which the instrument that was selected reflected the reality of the constructs that were being measured (Newsome 2016:58). To ensure validity, the 
TABLE 1: Accuracy analysis statistics: Reliability tests.

\begin{tabular}{|c|c|c|c|c|c|c|c|c|}
\hline \multirow[t]{2}{*}{$\begin{array}{l}\text { Research } \\
\text { construct }\end{array}$} & \multicolumn{2}{|c|}{$\begin{array}{l}\text { Descriptive } \\
\text { statistics }\end{array}$} & \multicolumn{2}{|c|}{$\begin{array}{l}\text { Cronbach's } \\
\text { test }\end{array}$} & \multirow[t]{2}{*}{ CR } & \multirow[t]{2}{*}{ AVE } & \multirow[t]{2}{*}{$\begin{array}{l}\text { Factor } \\
\text { loading }\end{array}$} & \multirow[t]{2}{*}{$\begin{array}{l}\text { Highest } \\
\text { SV }\end{array}$} \\
\hline & Mean & SD & $\begin{array}{l}\text { Item } \\
\text { total }\end{array}$ & $\begin{array}{l}\text { Alpha } \\
\text { value }\end{array}$ & & & & \\
\hline E-design & 4.62 & 0.56 & - & 0.71 & 0.88 & 0.60 & - & 0.47 \\
\hline ED 1 & - & - & 0.53 & - & - & - & 0.57 & - \\
\hline ED 2 & - & - & 0.48 & - & - & - & 0.48 & - \\
\hline ED 3 & - & - & 0.40 & - & - & - & 0.54 & - \\
\hline ED 4 & - & - & 0.48 & - & - & - & 0.59 & - \\
\hline ED 5 & - & - & 0.46 & - & - & - & 0.58 & - \\
\hline E-negotiation & 4.70 & 0.54 & - & 0.72 & 0.88 & 0.84 & - & 0.66 \\
\hline EN 1 & - & - & 0.51 & - & - & - & 0.63 & - \\
\hline EN 2 & - & - & 0.65 & - & - & - & 0.79 & - \\
\hline EN 3 & - & - & 0.55 & - & - & - & 0.68 & - \\
\hline $\begin{array}{l}\text { Supplier } \\
\text { integration }\end{array}$ & 4.46 & 0.99 & & 0.89 & 0.88 & 0.84 & - & 0.57 \\
\hline SI 1 & - & - & 0.52 & - & - & - & 0.55 & - \\
\hline SI 2 & - & - & 0.64 & - & - & - & 0.65 & - \\
\hline SI 3 & - & - & 0.70 & - & - & - & 0.67 & - \\
\hline SI 4 & - & - & 0.72 & - & - & - & 0.79 & - \\
\hline SI 5 & - & - & 0.70 & - & - & - & 0.79 & - \\
\hline SI 6 & - & - & 0.69 & - & - & - & 0.72 & - \\
\hline SI 7 & - & - & 0.70 & - & - & - & 0.68 & - \\
\hline
\end{tabular}

$\mathrm{SD}$, standard deviation; $\mathrm{CR}$, composite reliability; $\mathrm{AVE}$, average variance extracted; SV, shared variance.

research study used three experts in supply chain management to judge the questions independently (Schindler 2010:65). Also, an extensive literature review was conducted to ensure that the instrument is related to previous studies. Thereafter, previous studies were consulted to construct the research instrument. To further ascertain validity in this study, a pilot study was conducted with a conveniently selected sample of 42 SME owners and managers in the Vaal Triangle region of Gauteng Province, South Africa. Input from the pilot sample was used to improve the questionnaire in terms of its wording and technical layout.

\section{Ethical consideration}

Participants were not forced to participate. Participants were also told that participation might be terminated at any given time with no adverse consequences should they wish not to continue with the study (completing the questionnaire). Information provided by participants or respondents was treated with utmost confidentiality and anonymity. The data were securely stored by the researcher and no one else had access to the data.

\section{Results and discussion}

The results of gender and experience of SME owners and managers are shown in Table 2 and Figure 2. This section covers the sample characteristics, testing for the unidimensionality of scales and hypothesis testing results.

\section{Sample characteristics}

Table 2 presents a graphical representation of the gender distribution of the sample. Males constitute $54.0 \%(n=153)$ and females constitute $46.0 \%(n=130)$ of the sample. Nieman and Nieuwenhuizen (2009:143) found that there are few women
TABLE 2: Gender of respondents.

\begin{tabular}{lcc}
\hline Gender & Number & $\mathbf{\%}$ \\
\hline Male & 153 & 54 \\
Female & 130 & 46 \\
\hline Total & $\mathbf{2 8 3}$ & $\mathbf{1 0 0}$ \\
\hline
\end{tabular}

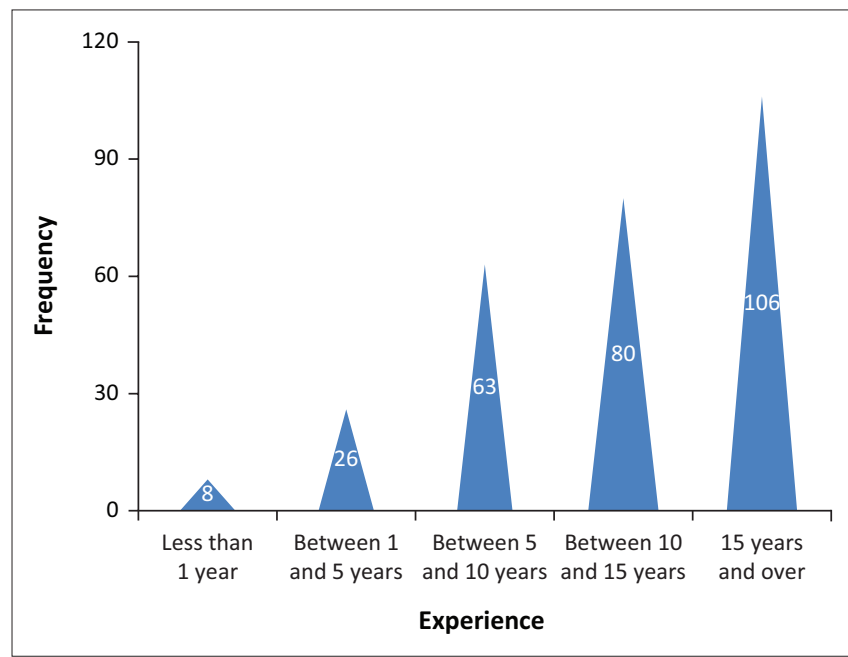

FIGURE 2: Experience in the industry.

owning or managing businesses because of start-up capital problems.

The study revealed that $2.8 \%(n=8)$ of respondents had served their organisations for less than 1 year. Approximately 9.2\% $(n=26)$ of respondents served their organisation between 1 and 5 years, while 22.3\% $(n=63)$ served the organisation between 5 and 10 years. Approximately 28.3\% $(n=80)$ of the sample had served their organisation between 10 and 15 years, while $37.5 \%(n=106)$ of the respondents served their organisation for more than 15 years.

Regarding the race or ethnicity, the African race constituted 201 $(72 \%)$, while coloureds were $18(6 \%)$. The white people were 62 , representing $21 \%$ of the sample, with other category with two respondents reflecting a $1 \%$. The qualifications of SME owners and managers were as follows: matric/no qualifications were 13 , degree/diploma were 259 , while those who hold master's degree were 8 and finally with $\mathrm{PhD} / \mathrm{D}-\mathrm{Tech}$ were 3 .

\section{Testing for the unidimensionality of scales}

The different scales used in the study were tested for unidimensionality through exploratory factor analysis. Prior to the factor analysis, the Bartlett's test of sphericity and the Kaiser-Meyer-Olkin (KMO) measure of sampling adequacy were computed to establish whether the data were suitable for factor analysis (see Table 3).

According to Chinomona (2012:341), the sampling is adequate if the value of KMO test is greater than 0.5 .

For this study, as indicated in Table 2, the KMO value is 0.753 , exceeding the recommended minimum of 0.5 (Cerny \& Kaiser 1977:43; Kaiser 1974:35). This shows that the feasibility of factor analysis is fulfilled. 
TABLE 3: Kaiser-Meyer-Olkin measure of sampling adequacy and Barlett's test.

\begin{tabular}{llc}
\hline Test & Variable & Measure \\
\hline $\begin{array}{l}\text { Kaiser-Meyer-Olkin measure of } \\
\text { sampling adequacy }\end{array}$ & - & 0.753 \\
Barlett's test of sphericity & Approx. chi-square test & 438.063 \\
& Degree of freedom & 34 \\
& Significance & 0.000 \\
\hline
\end{tabular}

The factor extraction through principal component analysis for each construct is reported in Table 4, indicating that only one factor was extracted for each variable. The principal component analysis was used to:

[C]ompress the maximum amount of information into first two columns of the transformed matrix known as the principal components by neglecting the other vectors that carries the negligible information or redundant data. (Pallant 2007:153; Pooe \& Mahlangu 2017:112)

Table 4 shows that the factor loadings for e-design were all were close to 0.7 except one statement which reads as follows: 'there is a design of the purchase requirement' and has a factor loading of 0.605 . E-negotiation factor loadings were all above the 0.7 threshold. In supplier integration, only one statement was below 0.7 .

\section{The hypotheses testing stage and results}

Structural equation modelling was used in this study to estimate the relationship between the constructs. Therefore, SEM seeks to understand the relationships between latent variables and the observed variables, which form the structural framework from which they are derived. Path analysis allows path coefficients (the relationship between variables) to be determined. In addition, path analysis requires recursivity (that the path direction is one way with no feedback loops) (Chinomona 2012:10 135). The advantage of path analysis is that the researcher can see which variables exert effects on others.

\section{Structural equation modelling conceptual model fit assessments}

Table 5 describes the SEM model fit indices results for this study.

As shown in Table 5, this study reports a chi-square/degree of freedom value of 1.46 as indicative of a good model fit. Table 5 further shows IFI, CFI and TLI values $(0.94,0.92$ and 0.95 , respectively) that are above the recommended threshold of 0.9 or above (Chinomona 2011:302, 2013:342). These results further confirm that the estimated model fits the sample data in this study well, which provides a good model fit. Table 4 also depicts a root mean square error of approximation (RMSEA) value of 0.04 , which provides a very good model fit (Chinomona et al. 2010:47; Pallant 2007). Overall, the model fit indices provide a good fit.

\section{E-design positively influences supplier integration in the small and medium enterprises sector (Hypothesis 1)}

A linear relationship (positive and significant) was hypothesised between e-design and supplier integration.
TABLE 4: Factor component matrix.

\begin{tabular}{|c|c|}
\hline Variable & Factor loadings \\
\hline \multicolumn{2}{|l|}{ E-design } \\
\hline $\begin{array}{l}\text { Each department within the company shares the same network } \\
\text { platform for procurement requests }\end{array}$ & 0.733 \\
\hline $\begin{array}{l}\text { Each department within the company requests purchases from } \\
\text { one specific department unit }\end{array}$ & 0.693 \\
\hline There is a design of the purchase requirement & 0.605 \\
\hline $\begin{array}{l}\text { The design of the purchase requirement or the standardised } \\
\text { purchasing norm between the organisation and the supplier } \\
\text { will be communicated or negotiated via the internet }\end{array}$ & 0.698 \\
\hline $\begin{array}{l}\text { Our company designs the format of marketing demands using } \\
\text { the information system }\end{array}$ & 0.679 \\
\hline \multicolumn{2}{|l|}{ E-negotiation } \\
\hline $\begin{array}{l}\text { Our company negotiates the general procedures of purchasing } \\
\text { with the supplier through the internet }\end{array}$ & 0.769 \\
\hline $\begin{array}{l}\text { The use of the internet for negotiations results in significant } \\
\text { savings for this company }\end{array}$ & 0.866 \\
\hline $\begin{array}{l}\text { The use of the internet for negotiations results in lower } \\
\text { purchase costs }\end{array}$ & 0.793 \\
\hline \multicolumn{2}{|l|}{ Supplier integration } \\
\hline $\begin{array}{l}\text { There is extensive participation with our major supplier in the } \\
\text { design stage }\end{array}$ & 0.617 \\
\hline $\begin{array}{l}\text { Our major suppliers share their production schedule with our } \\
\text { company }\end{array}$ & 0.733 \\
\hline $\begin{array}{l}\text { Our major suppliers share their production capacity with our } \\
\text { company }\end{array}$ & 0.775 \\
\hline Our major suppliers share available inventory with our company & 0.801 \\
\hline Our company shares production plans with its major suppliers & 0.787 \\
\hline Our company shares demand forecasts with its major suppliers & 0.777 \\
\hline Our company shares inventory levels with its major suppliers & 0.784 \\
\hline $\begin{array}{l}\text { Our company helps its major suppliers to improve their } \\
\text { processes to better meet the needs of our company }\end{array}$ & 0.747 \\
\hline
\end{tabular}

TABLE 5: Structural equation modelling model fit indices results.

\begin{tabular}{ll}
\hline Measures & Values \\
\hline Contrast media-induced nephropathy (CMIN) & 1038.61 \\
Chi-square/ $f f$ & 1.46 \\
The incremental fit index (IFI) & 0.94 \\
The Tucker-Lewis index (TLI) & 0.92 \\
The comparative-fit-index (CFI) & 0.95 \\
The root mean square error of approximation (RMSEA) & 0.04 \\
\hline$d f$, degree of freedom. &
\end{tabular}

TABLE 6: Hypothesis 1 structural equation modelling results.

\begin{tabular}{lcccccc}
\hline Variables Path Variables & Hypothesis & $\begin{array}{c}\text { Path } \\
\text { coefficient }\end{array}$ & $\begin{array}{c}\text { Standard } \\
\text { error }\end{array}$ & $\begin{array}{c}\text { Critical } \\
\text { region }\end{array}$ & $p$ \\
\hline E-design $\rightarrow$ & $\begin{array}{l}\text { Supplier } \\
\text { integration }\end{array}$ & H1 & 0.33 & 0.153 & 2.126 & $<0.05$ \\
\hline
\end{tabular}

Structural model fit: Note significance level: ${ }^{*}, p<0.1$ (insignificant); ${ }^{* *}, p<0.05$ (significant); $* * *, p<0.001$ (significant).

This hypothesis was formulated from the objective that aimed to investigate the influence of e-design on supplier integration. Results are shown in Table 6.

As shown in Table 6, e-design has a positive and significant linear relationship with supplier integration. H1 is therefore supported. This study posited a positive influence of e-design on supplier integration and the results of this study confirmed it. A positive path coefficient $(\beta=0.33 ; p<0.05)$ validates the hypothesised positive influence that e-design has on supplier integration. These findings mean that SMEs that effectively implement e-design systems, integrating with their suppliers, increase their chances of improving performance and cutting supply chain costs.

These findings are consistent with those of Chang and Wong (2012:342), who posit that e-design is the infrastructure aspect 
that brings in higher levels of partnerships and improved supply chain performance. This notion is also supported by Shank and Brown (2007:190), who found that successful companies or firms using e-design systems effectively ultimately lead to greater supplier integration. Therefore, superior e-design systems are associated with greater supplier integration.

Thus, validation of a positive influence of e-design on supplier integration means that if SMEs effectively implement e-design systems they increase their chances of collaborating with their key supply chain members and this may result in minimisation of costs such as supply chain costs, thus consequently improving supply chain performance. These findings further suggest that supply chain member firms that invest in and use e-design tools for their buying and selling with each other can learn collectively and create a strong supplier integration.

\section{E-negotiation positively influences supplier integration in the small and medium enterprises sector (Hypothesis 2)}

A positive and significant influence of e-negotiation on supplier integration was posited. The SEM results that validate or invalidate this hypothesis are shown in Table 7.

As shown in Table 7, e-negotiation has a positive and significant relationship with supplier integration. $\mathrm{H} 2$ is therefore supported. This study posited a positive influence of e-negotiation on supplier integration. A positive path coefficient ( $\beta=0.175 ; p<0.1)$ validates the hypothesised positive influence that e-negotiation has on supplier integration.

A positive path coefficient may be because suppliers collaborate more often when they do their contract agreements electronically. These contract agreements will, in turn, improve their relations in business, and thus contribute to higher levels of engagement and consequently improve supply chain performance. As posited in $\mathrm{H} 2$, the findings of this study suggest that in the firms surveyed there are some contract negotiations taking place with suppliers through technology.

\section{Conclusion}

To achieve the first hypothesis, the SEM test was conducted to examine the effect of e-design on supplier integration. The test revealed a statistically positive and significant relationship. These findings mean that firms that effectively implement e-design systems, integrating with their suppliers, increase their chances of improving performance as well as cutting supply chain costs.

\begin{tabular}{lcccccc} 
TABLE 7: Hypothesis 2 structural equation modelling results. \\
\hline Variables & Path Variables & Hypothesis & $\begin{array}{c}\text { Path } \\
\text { coefficient }\end{array}$ & $\begin{array}{c}\text { Standard } \\
\text { error }\end{array}$ & $\begin{array}{c}\text { Critical } \\
\text { region }\end{array}$ & $p$ \\
\hline E-negotiation $\rightarrow \rightarrow$ & $\begin{array}{l}\text { Supplier } \\
\text { Integration }\end{array}$ & H2 & 0.175 & 0.103 & 1.969 & $<0.1$ \\
\hline
\end{tabular}

Structural model fit: Note significance level: ${ }^{*}, p<0.1$ (insignificant); ${ }^{* *}, p<0.05$ (significant) $* * *, p<0.001$ (significant).
To achieve the second hypothesis, the SEM test was conducted to examine the effect of e-negotiation on supplier integration. The test revealed a statistically positive and significant relationship. Thus, the findings of this study suggest that in the firms surveyed there are some contract negotiations taking place with suppliers through technology. Therefore, this study concludes that firms can use e-design and e-negotiation systems to enhance supplier integration.

\section{Managerial implications}

The results of this study showed that e-design has a positive influence on supplier integration. This serves as an implication that SME owners and managers should begin to work towards developing a deeper understanding of e-design tools and systems - so that they can develop strategies that will contribute to the improvement of supplier integration, which will, in turn, positively influence supply chain performance.

Therefore, it means that the SME owners and managers should invest more in e-design systems for their buying and selling as this will create further collaborations.

The results also showed that e-negotiation has a positive influence on supplier integration. Therefore, it is recommended that SME owners and managers recognise e-negotiation as an important e-procurement element to foster ongoing relationships with supply chain member firms. SME owners and managers must also enrol for e-procurement training workshops or courses. This training should emphasise the importance of e-procurement functions such as e-design and e-negotiation as the key drivers of supplier integration.

\section{Contribution of the study}

Firstly, a contribution is made to the existing literature on SMEs in South Africa, which was noted to be scant.

The study developed an integrative model, which might be used by SME practitioners in South Africa, thus contributing to the existing literature. Because the model paid attention to e-procurement (e-design and e-negotiation) and supplier integration, possible strategies such as investing in supplier collaborations through e-procurement could be derived from the model. Thus, SME owners and managers will be in a better position to increase the levels of supply chain performance within their firms. Overall, the findings reveal that by investing in e-procurement functions such as e-design and e-negotiation, SMEs can improve their own performance through good supplier collaborations. The findings of this study are also important to other SMEs in South Africa. They may use these findings as a benchmark for the best practices in supply chain management (SCM) and e-procurement practices.

\section{Limitations and directions for future research}

The use of only SME owners and managers as chief informants in the survey could be a limitation. Data were collected only from SME owners and managers; future 
research could broaden the scope to include customers, manufacturers (suppliers) and low-level subordinates.

E-procurement is a multidimensional concept and the study investigated only two important dimensions, namely, e-negotiation and e-design. There are many other e-procurement functions, such as e-sourcing, e-evaluation, e-informing, e-payment, e-catalogue, e-tendering, e-tailing, e-purchasing and e-transportation, among others. Future research should investigate the relationship between other e-procurement functions, supplier integration and supply chain performance.

Because this study adopted only the quantitative approach, another study involving a qualitative approach or a mixedmethod approach is recommended as this will provide an indepth analysis.

\section{Acknowledgements}

The author is grateful to Almighty God and his beloved family. This research was drawn from a thesis submitted by the author at Vaal University of Technology in 2018.

\section{Competing interests}

The author declares that he has no financial or personal relationships that may have inappropriately influenced him in writing this article.

\section{Author's contributions}

I declare that I am the sole author of this article.

\section{Funding information}

This research received no specific grant from any funding agency in the public, commercial or not-for-profit sectors.

\section{Data availability statement}

Data sharing is not applicable to this article as no new data were created or analysed in this study.

\section{Disclaimer}

The views and opinions expressed in this article are those of the author and do not necessarily reflect the official policy or position of any affiliated agency of the author.

\section{References}

Boehmke, B.C. \& Hazen, B.T., 2017, 'The future of supply chain information systems: The open source ecosystem', Global Journal of Flexible Systems Management 18(2), 163-168. https://doi.org/10.1007/s40171-017-0152-x

Cerny, C.A., \& Kaiser, H.F. 1977, 'A study of a measure of sampling adequacy for factoranalytic correlation matrices', Multivariate Behavioral Research 12(1), 43-47. https://doi.org/10.1207/s15327906mbr1201_3

Chang, H.H. \& Wong, K.H., 2012, 'Adoption of e-procurement and participation of e-marketplace on firm performance: Trust as a moderator', Information \& Management 47(5-6), 262-270. https://doi.org/10.1016/j.im.2010.05.002

Chang, H.H., Tsai, Y.C. \& Hsu, C.H., 2013, 'E-procurement \& supply chain performance', International Journal of Management 18(1), 34-51. https://doi.org/10.1108/ 13598541311293168
Chinomona, R., 2011, 'Non-mediated channel powers and relationship quality: A case of SMES in Zimbabwe channels of distribution', Unpublished PhD thesis, National Central University, Taiwan.

Chinomona, R. 2012, 'The influence of dealers' referent power and legitimate power in Guanxi distribution networks: The case of Taiwan's SMEs firms', African Journal of Business Management 6(37), 10125-10137. https://doi.org/10.5897/ of Business

Chinomona, R., 2013, 'Dealers' legitimate power and relationship quality in Gaunxi distribution channel: A social rule system theory perspective', International Journal of Marketing Studies 5(1), 42-58. https://doi.org/10.5539/ ijms.v5n1p42

Chinomona, R., Lin, J., Wang, M. \& Cheng, J. 2010, 'Soft power and desirable relationship outcomes in Zimbabwe distribution channels', African Journal of Business 11(2), 20-55. https://doi.org/10.1080/15228916.2010.508997

Chirchir, E.K., Ngeno, V. \& Chapkwony, J., 2015, 'Relationship between e-procurement adoption \& supply chain management practices in tea firms', International Journal of Managerial Studies \& Research 3(2), 25-36.

Flynn, B.B., Hou, B. \& Zhao, X., 2010, 'The impact of supply chain integration on performance: A contingency \& configuration approach', Journal of Operation Management 28, 58-71. https://doi.org/10.1016/j.jom.2009.06.001

Georgise, F.B., Thoben, K. \& Seifert, M. 2014, 'Supply chain integration in the manufacturing firms in developing country: An Ethiopian case study', Journal of Industrial Engineering, Article no. 251982, 1-13. https://doi.org/10.1155/2 014/251982

Government Gazette, 2003, No 26 National Small Business Amendment Act, Parliament of the Republic of South Africa 461, pp. 1-10, Cape Town.

Gumboh, J. \& Gichira, R., 2015, 'Supply chain collaboration among SMEs in Kenya: A review of collaboration barriers', International Journal of Humanities and Social Science 5(9), 223-229.

Kaiser, H. 1974, 'An index of factor simplicity', Psychometrika 39, 31-36. https://doi. org/10.1007/BF02291575

Mccue, C. \& Roma, A., 2012, 'E-procurement: Myth or reality?', Journal for Public Procurement 5(1), 54-72.

Miller, D., 1986, 'Configuration of strategy and structure: Towards a synthesis', Strategic Management Journal 7(3), 233-249. https://doi.org/10.1002/ smj.4250070305

Mishra, A.N. \& Agarwal, R., 2010, 'Technological frames, organizational capabilities, and it use: An empirical investigation of electronic procurement', Information Systems Research 21(2), 249-270. https://doi.org/10.1287/isre.1080.0220

Newsome, B.O., 2016, An introduction to research, analysis and writing: practical skills for social science students, Sage, Thousand Oaks, CA.

Nieman, G.H. \& Nieuwenhuizen, C., 2009, Entrepreneurship: A South African perspective, Van Schaik Publishers, Pretoria.

Njagi, M.M. \& Ogutu, M., 2014, 'Role of supply chain integration on supply chain performance in Kenyan State Corporations', International Journal of Current Business and Social Sciences 1(2), 188-204.

Ombat, K.O., 2015, 'The relationship between procurement systems and performance of procurement function in commercial banks in Kenya', International Journal of Economics, Commerce and Management 3(12), 697-723.

Pallant, J., 2007, SPSS survival manual: A step by step guide to data analysis using SPSS for windows, 3rd edn., McGraw-Hill Open University Press, New York, NY.

Pooe, R.I.D. \& Mahlangu, D., 2017, 'Enhancing SME performance through supply chain integration, collaborative planning, and supply chain capabilities', Journal of Contemporary Management 14, 238-269.

Prajogo, D.I., Oke, A. \& Olhager, J., 2015, 'Supply chain processes: Linking supply logistics integration, supply performance, lean processes and competitive performance', International Journal of Operations \& Production Management 30(3), 312-335.

Presutti, W.D., 2003, 'Supply management and e-procurement: Creating value added in the supply chain', Industrial Marketing Management 32(3), 219-226. https:// doi.org/10.1016/S0019-8501(02)00265-1

Rinderle-Ma, S., 2005, Towards the automation of e-negotiation process based on web services - A modeling approach', Journal of Procurement Management 6, 1-12.

Schindler, P., 2010, Business research methods, McGraw-Hill, London.

Scot, M. \& Morrison, P., 2007, Towards a structured design of electronic negotiations, Wardsworth Cengage Learning, New York.

Shank, J. \& Brown, D., 2007, 'Procurement: The missing link in innovation', Supply Chain Management Review 10(1), 22-28.

Sinha, K., Kingshuk, K., Van De Ven, H. \& Andrew, H., 2005, 'Designing work within and between organisations', Organisational Sciences 16(4), 389-408. https://doi. org/10.1287/orsc.1050.0130

Smart, A.F., 2010, 'E-procurement and its impact on supply management - Evidence from industrial case studies', International Journal of Logistics: Research and Applications 13(6), 423-440. https://doi.org/10.1080/13675567.2010.486760

Smuts, H., 2008, 'Determinants of supplier-retailer collaboration: Evidence from an international study', International Journal of Operations and Production Management 26(1), 24-49. https://doi.org/10.1108/01443570610637003

Tai, Y.M., 2011, 'Exploring the performance impact of web based direct procurement systems', International Journal of Production Research 48(18), 5397-5414. https://doi.org/10.1080/00207540903117915 
Vaast, E. \& Walsham, G., 2017, 'Trans-situated learning: Supporting a network of practice with an information infrastructure', Information Systems Research 20(4), practice with an information infrastructure', Inform
$547-564$. https://doi.org/10.1287/isre.1080.0228

Ward, P.T., Bikford, D.J. \& Leong, G.K., 1996, 'Configurations of manufacturing strategy, business strategy, environment and structure', Journal of Management 22(4), 597-626.

Wong, A.S.H., Tjosvold, D. \& Yu, Z.Y., 2005, 'Organisational partnerships in China: Selfinterest, goal independence \& opportunism', Journal of Applied Psychology 90(4) 782-791. https://doi.org/10.1037/0021-9010.90.4.782

Yu, W., Chavez, R., Feng, M., \& Wiengarten, F., 2014, 'Integrated green supply chain management and operational performance', Supply Chain Management: An International Journal 19(5/6), 683-696. https://doi.org/10.1108/SCM-07-2013-0225

Zarenda, H., 2013, South Africa's national development plan and its implications for regional development, pp. 1-7, Tralac, Stellenbosch.
Zhao, G., Feng, T. \& Wang, D., 2015, 'Is more supply chain integration always beneficial to financial performance?', Industrial Marketing Management Journal 45 , 162-172. https://doi.org/10.1016/j.indmarman.2015.02.015

Zhao, X., Huo, B., Selen, W. \& Yeung, J.H.Y., 2011, 'The impact of relationship commitment on the integration between manufacturers and customers in a supply chain', Journal of Operations Management 29(1-2), 368-388. https://doi. org/10.1016/j.jom.2007.08.002

Zhao, X.B., Huo, B.B., Flynn, B. \& Yeung, L., 2008, 'The impact of power and relationship commitment on the integration between manufacturers and customers in a supply chain', Journal of Operations Management 26(3), 368-388. https://doi. org/10.1016/j.jom.2007.08.002

Zheng, J., Bakker, E., Knight, L., Gilhespy, H., Harland, C. \& Walker, H., 2016, 'A strategic case for e-adoption in healthcare supply chains', International Journal of Information Management 26, 290-301. https://doi.org/10.1016/j.jijinfomgt.2006.03.010 